DOI: 10.20472/IAC.2020.056.010

\title{
NICOLETA-DANIELA MILU
}

West University of Timisoara, Romania

\section{HUMAN CAPITAL A KEY ELEMENT OF CORPORATE SOCIAL RESPONSIBILITY IN THE CONTEXT OF DIGITALISATION}

\begin{abstract}
:
Digitalisation is equally about technology, innovation and how it transforms people's lives in the workplace. When an organization goes through a digital transformation, it must first take into account the main factor that determines the success of this process: employees. If employees are not prepared for this stage of change and remain faithful to old processes, the company will not be able to build products and experiences that meet the demands of today's consumers. The path to a sustainable business begins with its employees. The main purpose of this paper is to analyze the digital skills of employees in European Union countries based on reports published by the European Commission in 2018-2019. The study shows that over half of the European Union countries have a low level of digital skills and should invest in employees, organize training courses and prepare them for the innovation process. To ensure its sustainability, a company must implement its own solutions, develop activities, train its employees so that they are prepared for the innovation process. The social responsibility of the companies regarding the employees appeared in the context in which the companies developed, they adopted new technologies and they focused on digitization. An important factor in the development of a sustainable company is the recruitment of those people who understand the company's sustainable development needs and who have the values, experience and skills necessary to develop and implement the sustainability strategy. Companies need motivated employees to work for the social and environmental aspects relevant to the business and who want to lay the foundations of the infrastructure for sustainability in the company.
\end{abstract}

\section{Keywords:}

CSR, Digital Economy and Society Index, Human Capital, sustainability, digitalisation

JEL Classification: M40, M20, M14 